IRA-International Journal of Management \& Social Sciences

ISSN 2455-2267; Vol.04, Issue 01 (2016)

Institute of Research Advances

http://research-advances.org/index.php/RAJMSS

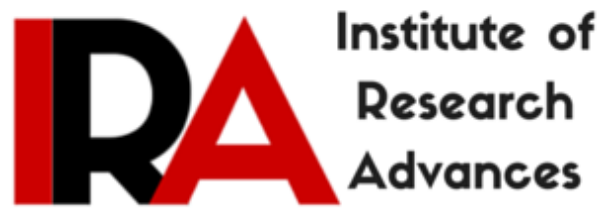

\title{
Teachers' code-switching in English as a Second Language (ESL) instruction: Perceptions of selected secondary school learners in Zimbabwe
}

\author{
Rugare Mareva, \\ Great Zimbabwe University, \\ Department of Curriculum Studies, \\ P.O. Box 1235, Masvingo, Zimbabwe.
}

DOI: http://dx.doi.org/10.21013/jmss.v4.n1.p11

\section{How to cite this paper:}

Mareva, R. (2016). Teachers' code-switching in English as a Second Language (ESL) instruction: Perceptions of selected secondary school learners in Zimbabwe. IRAInternational Journal of Management \& Social Sciences (ISSN 2455-2267), 4(1). doi:http://dx.doi.org/10.21013/jmss.v4.n1.p11

(C) Institute of Research Advances

\section{(c)) EY-NC}

This works is licensed under a Creative Commons Attribution-Non Commercial 4.0 International License subject to proper citation to the publication source of the work.

Disclaimer: The scholarly papers as reviewed and published by the Institute of Research Advances (IRA) are the views and opinions of their respective authors and are not the views or opinions of the IRA. The IRA disclaims of any harm or loss caused due to the published content to any party. 


\begin{abstract}
The study explored perceptions of secondary school learners of English on code-switching by teachers in the teaching of English. The qualitative inquiry focused on one rural day, and one urban boarding school. The study employed focus group discussions with groups of ten Form One and ten Form Three English learners per school. Results show that from the perspective of the learners, their ESL teachers code-switched from English to the learners' L1 as a teaching and learning tool, mainly to foster understanding among learners and between the learners and their teachers, and for other communicative functions. The majority of the learners expressed an appreciation of their teachers' code-switching but there were also negative sentiments. The study recommends that language policy planners revisit the English-only policy in the school and consider adopting the endo-normative rather than the exo-normative model of English for the education system. The study also recommends that the Ministry Education should hold workshops to sensitise teachers on how code-switching may best be employed as an instructional tool. Furthermore, the study recommends that ESL teachers be guided by the Postmethod pedagogy, a sense of plausibility as well as the notion of relativism in their decisions on code-switching. In addition, the inquiry recommends that the Zimbabwe Schools Examinations Council be sensitive to aspects of the local variety of English rather than set exonormative models. Finally, the study recommends that further research be done on code-switching in school types which were not included in the sample for the present study.
\end{abstract}

Key Words: Code-switching, English, Target Language, Approaches, Methods

\title{
1.0 Background: The Linguistic Situation in Zimbabwe
}

Located in Southern Africa, Zimbabwe, a former British colony, has a population of about 13 million according to the latest (2013) national census results. The linguistic situation in the country is that Zimbabwe is a multilingual country where there are 16 spoken languages (Hachipola, 1998). Of these, until the Constitution of Zimbabwe Amendment (No. 20) Act of 2013, English has been the official language while Shona and Ndebele have been national languages spoken by $70 \%$ and $15 \%$ of the population, respectively (Peresuh and Masuku, 2002). The others have been regarded as minority languages and these include Shangani, Venda, Kalanga, Nambya, Tonga, Chichewa, Sotho, Chikunda, Sena, Barwe, Hwesa, and Tshwawo (Chimhundu, 1997).

However, the Constitution of Zimbabwe Amendment (No. 20) (2013) raised the status of Shona, Ndebele, Chewa, Chibarwe, English, Kalanga, Koisan, Nambya, Ndau, Ndebele, Shangani, Shona, sign language, Sotho, Tonga, Tswana, Venda and Xhosa, to official languages of Zimbabwe.

Nevertheless, the place of English in Zimbabwe is that, like in many other former British colonies, the language continues to enjoy a higher social status than any of the indigenous languages since, for many years, it has been the only official language (Kadenge and Mabugu, 2009), yet English is the home language of less than 1\% of the population (Peresuh and Masuku, 2002). English is the main language of international and intranational business, government, legislation religion, advertisements, political manifestos, and other important documents (Mabugu, 2009). English 'has remained the language of instruction in the private and public schools. It remains the language of the office. Furthermore, the ' $\mathrm{O}$ ' level school-leaving certificate cannot be complete unless one passes... English of course' (Mavhunga, 2006:447-448). English is, thus, perceived to be an economic gatekeeper (Nyawaranda, 2000).

Zimbabwe's national language policy on education as contained in the Education Act of 1987 (as amended in 1990) and as quoted in Nziramasanga (1999) stipulates that Shona, Ndebele and English, shall be taught in all primary schools from the first grade as follows with Shona and Ndebele being taught in all areas where they are the mother tongues of the majority of the residents. Also, prior to the fourth grade, Shona, Ndebele or English may be used as a medium of instruction, depending upon which language is most commonly spoken and better understood by the pupils. From the fourth grade, English shall be the medium of instruction provided that Shona or Ndebele shall be taught as subjects. 
In areas where minority languages exist, the Minister may authorise the teaching of such languages in primary schools.

However, Amended Education Act of 2006 stipulates that indigenous languages may be used as media of instruction throughout the primary school level, while English becomes the sole medium of instruction from Form One of secondary education.

What is clear from the linguistic situation in Zimbabwe, thus, is that English exists side by side with a plethora of indigenous languages and therefore, code-switching from English to either of the local languages, or vice versa, is bound to occur.

\subsection{Statement of the Problem}

The problem that has motivated this study lies in Zimbabwe's language policy on instruction, and the controversy surrounding the role of the learners' L1 in L2 instruction. Zimbabwe's language policy on instruction stipulates that English be the sole language of instruction in the teaching of all subjects (including of course English itself) except in the teaching of local languages as subjects, from Form One (Nziramasanga, 1999).Yet there is apparently never-ending debate regarding the role of the L1 in L2 instruction and in teaching and learning in general. As Storch and Wigglesworth (2003:760) aptly put it, 'The use of learners' L1 is a controversial issue in L2 education.' El-dali (2010) also acknowledges the existence of controversy regarding the use or avoidance of the L1 in the L2 classroom. Sachiko (cited in Nyawaranda, 2000) also observes that there are differences in opinion among teachers on the role of the mother tongue in instruction and these opinions reflect the differences in the teachers' wider beliefs about the best way to learn a language.

\subsection{Significance of the Study}

Against the backdrop of Zimbabwe's language policy on instruction which stipulates that English be the sole medium of instruction from the secondary school level upwards (Zimbabwe Amended Education Act, 2006) and against the backdrop of the controversy surrounding the role of learners L1 in L2 instruction (Al-Nofaie, 2010; Kafes, 2011) this study is significant in that it seeks to unearth the perceptions of secondary school learners on their teachers' use of code-switching in the teaching of English in Zimbabwe.

\subsection{Objectives of the Study}

The study sought to:

(a) find out, from the perspective of selected learners, if secondary school teachers in Zimbabwe code-switch in ESL lessons and in what situations.

(b) establish the selected and learners' perceptions on their teachers' use of code-switching in the teaching of ESL.

\subsection{Literature Review}

\subsection{Role of the Learners' $L 1$ in the L2 Classroom}

One of the issues that have taken centre stage in the field of bilingualism and language teaching is whether or not the learners L1 should be used in the classroom. Macaro (2014) refers to the 'virtual' position, in which case the teacher's belief is that the whole teaching and learning process should be in the target language, the 'maximal' position in which while the teacher may agree in principle that all teaching and learning should be in the target language, he or she concedes, though begrudgingly, that in reality some L1 will be used because of the learners' low target language proficiency. Then there is the 'optimal' position, in which the teacher sees the L1 as playing a beneficial role in the teaching and learning of the L2 but has to be aware of both the pros and cons of using the L1 in the classroom. This study, thus, seeks to establish the beliefs of the selected secondary school teachers on the role of the learners' L1 in L2 teaching and learning. 
Al-Nofaie (2010), and Kafes (2011), identify two schools of thought that have either advocated for, or rejected the use of the L1 in L2 teaching and learning. These are the Bilingual Approach and the Monolingual Approach, respectively.

While the Bilingual Approach accepts or encourages use of learners' L1 in L2 teaching and learning, in monolingual teaching 'the teaching itself, as well as the organisation of the work in the classroom, should take place in the target language' (Simensen, 2007:236). This was advocated by the Reform Movement in the advent of the Direct Method, in which 'teaching in the target language itself would establish direct associations or links between L2 items and the things, actions, and the states talked about' (Simensen, 2002:26). Cook (2001) observes that over the last century, use of the L1 in L2 learning has largely been regarded as taboo and was therefore banned or minimised. Cook also states that proponents of the Monolingual Approach argue that, firstly, the learning of an L2 should be modelled on the learning of an L1, that is, through maximum exposure to the L2. Secondly, the advocates claim that successful learning involves the separation and distinction between the L1 and the L2. Thirdly, it is argued that students should be shown the importance of the L2 by its continual use. Furthermore, the rationale behind the Monolingual Approach is that the more students are exposed to the target language (TL), the more quickly they will learn it and as they learn and use it, they internalise it to begin to think in it. Also, the only way that learners will learn the TL is if they are forced to use it (Auerbach, cited in Sharma, 2006). In the words of Cook (2008:95), 'the purpose of language teaching in one sense is to provide optimal samples of language for the learner to profit from - the best 'input' to the process of language learning.'

Moreover, according to Macaro (2001:551), proponents of L2 exclusivity argue that 'teaching entirely through the TL makes the language real, allows learners to experience unpredictability, and develops the learners' own in-built language system.'

However, many authors advocate for the use of the L1 in the L2 classroom and articulate the many benefits of doing so. These include Corder (1992), Harbord (1992), Brown (2000), Nyawaranda (2000), Cook (2001, 2002, 2012), Deller and Rinvolucri (2002), Miles (2004), Choong (2006), Nguyen (2010) and Atkinson, Collingham, Piasecka, (all cited in Al-Nofaie, 2010).

\subsection{Other Views on Language Teaching}

On methods of English Language teaching, Larsen-Freeman (2000) rejects absolutism - the belief that one single method can be the best - and calls for relativism and pluralism. While relativism recognises that methods have their strengths and weaknesses and are therefore not practical for all contexts, pluralism advocates synthesising of different methods, thus recognising the value of each method. Larsen-Freeman (2000:182) states that ' ...rather than adopting or rejecting methods in their entirety as being suitable or unsuitable for a particular context, different methods, or parts of methods, should be practised in the same teaching context.' By implication, therefore, Larsen-Freeman seems to be calling for the fusion of monolingual and bilingual L2 teaching methods. This study is, thus interested in finding out the language choices of the L2 (English) teachers in the English classroom.

Perhaps an L2 teacher's decision on whether to use or not to use the L1 in the L2 classroom could be guided by Kumaravadivelu's (2006) Postmethod pedagogy. Kumaravadivelu (2006:171) says postmethod pedagogy is pedagogy that 'must be sensitive to a particular group of teachers teaching a particular group of learners pursuing a particular set of goals within a particular institutional context embedded in a particular socio-cultural milieu.' Apart from this aspect of particularity (sensitivity to context), Kumaravadivelu also states that post-method pedagogy is also characterised by practicality (teacher-generated theory of practice), and possibility (a critical reflection of prevailing social and historical conditions). These three aspects of particularity, practicality and possibility 'interact with each other in a synergic relationship where the whole is greater than the sum of its parts' (Kumaravadivelu, 2003:545). Therefore, whether or not the L2 teacher should or should not employ the language learners' L1 could be guided by Kumaravadivelu's notions of particularity, practicality and possibility. However, post-method pedagogy clearly recognises the important role played by the L1 in L2 teaching and learning, as one of the principles of the pedagogy is that the teacher should 
ensure social relevance. Kumaravadivelu (2003) actually suggests that the L1 is a rich resource that enables the teacher to make a link between the home language and the TL, thereby ensuring social relevance. Kumaravadivelu, thus, seems to encourage code-switching between the target language and the learners' L1, which is the focus of this inquiry.

Related to Kumaravadivelu's Post-method pedagogy is what Prabhu (1990) terms 'a sense of plausibility' defined as a sense of a teacher's subjective understanding or personal conceptualisation of teaching carried out in the classroom and their envisaged effect, a kind of pedagogical intuition that emanates from a teacher's experience as a learner, teacher, exposure to teaching methods, what the teacher knows or thinks about other teachers' actions or opinions, and the teacher's experience as a parent or caretaker. Prabhu (1990:173) then articulates the importance of the teacher engaging the sense of plausibility thus:

'It is when the teacher's sense of plausibility is engaged in the teaching operation that a teacher can be said to be involved, and the teaching not to be mechanical. Further, when a sense of plausibility is engaged, the activity of teaching is productive.'

By implication, therefore, Prabhu seems to advocate code-switching if the L2 teacher sees it as plausible.

Also, similar to Prabhu's sense of plausibility is Gebhard and Oprandy's (1999) argument that instead of being concerned with a search for the best method, the teacher should be concerned with the learner and trying to find out what works for them. Thus, by implication, the L2 teacher should codeswitch or avoid code-switching if he or she sees this as what is best for the learner.

In the same vein, Tribble (1997) calls for teacher independence, avoidance of fixed ideas, and promotion of fashionable formulas, exploration of principles and experimenting with techniques in the classroom.

Also in support of flexibility on the part of teachers is Tomilnson (2005:143), who argues that 'flexible, weak versions of pedagogic approaches, which encourage teacher variation within a recommended framework, have a much better chance of helping teachers to help their learners to learn.'

\subsection{Code-switching}

Code-switching, a common phenomenon among bilinguals (Malmkjaer, 1991), is defined by Eldridge (1996:303) as 'the alternation between two (or more) languages.' Nunan and Carter (2001:275) define code-switching as 'a phenomenon of switching from one language to another in the same discourse.' Fromkin and Rodman (1998) view code-switching as a universal language contact phenomenon reflecting the grammars of two languages working simultaneously and it occurs where there are groups of bilinguals who speak the same two languages. To Cook (2008:174) code-switching is conceptualised as 'going from one language to the other in mid-speech when both speakers know the same two languages.' To Simensen (2007), however, code-switching can entail merely borrowing one or more words from the native language. Myers (2008:43) gives a language-learner-specific definition of code-switching by defining the phenomenon as 'a linguistic term usually used when learners of a second language (L2) include elements of their mother tongue in their speech.'

\subsubsection{Code-switching in Educational Settings}

Many other studies have been carried out on the subject of code-switching in educational settings and the phenomenon was found to be prevalent, though sometimes an unconscious activity. Codeswitching in educational settings is viewed by Macaro (2009) as similar to the code-switching activities that occur in various real-life situations, such as the ones explored in the preceding subsection. Macaro (2005:72) also observes that code-switching is a common phenomenon in the L2 classroom where the learners share the same mother tongue, and that code-switching by L2 teachers 
'has no negative impact on the quantity of students' L2 production', but may actually increase and improve $\mathrm{L} 2$ production if expertly done.

Macaro (2005) also argues that teachers who are deprived of code-switching from their tool kit are unable to offer their learners translation as a learning task, yet translation is a valuable language skill that learners are very likely to need in the outside world. Apart from that, such teachers find it hard to offer learners pre-learning activities which trigger appropriate combinations of listening strategies since learners are likely to react more positively to the task at hand if they are assured in their mother tongue. Furthermore, avoiding code-switching will inhibit the use of certain classroom activities which are useful. 'There is nothing unnatural or 'psycholinguistically disturbing' about codeswitching in the classroom. It just mirrors a natural process happening in naturalistic discourse' (Macaro, 2005:80).

Ferguson, (cited in Baker 2006:295) observes that code-switching:

is not only very prevalent across a wide range of educational settings but also seems to arise naturally, perhaps inevitably, as a pragmatic response to the difficulties of teaching content in a language medium over which pupils have no control. Moreover, because teaching is an adrenalin-fuelled activity, making numerous competing demands on one's attentional resources, much switching takes place below the level of consciousness. Teachers are often simply not aware of when they switch languages, or indeed if they switch at all.

Sert (2005) also observes that the use of code-switching by teachers is not always done consciously so the teacher is not always conscious of the functions and outcomes of code-switching.

While Simon (2001) avers that code-switching in the classroom may be influenced by the teacher's desire to make use of all the possible available means to facilitate learning, Baker (2006:296) observes that 'The use of two languages in the classroom is all about which language is relatively valued, privileged, how use of two languages are synchronized and sequenced, negotiated and switched, how meanings and understandings are constructed.'

On what language teachers think about code-switching, Macaro (2005:68) observes that although studies seem to show that bilingual teachers believe that 'the L2 should be the predominant language of interaction in the classroom ... in none of the studies I have come across is there a majority of teachers in favour of excluding the L1 altogether.' Macaro (2005: 68) also states that research findings 'suggest that the teachers in the secondary sector use more L1 with 'less able' learners because these learners find it more difficult to infer meaning and therefore get more easily frustrated.' To Macaro, thus, L2 teachers' recourse to the learners' L1 is almost entirely for the purpose of achieving learner comprehension.

On what L2 learners' think about teachers' code-switching, Macaro (2005) says some (slow) learners get frustrated when they cannot understand the teacher's L2 input and are, thus, comfortable with the teacher's code-switching so as to get meanings of words and phrases. However, even with fast learners, there is no evidence that higher fast learners feel more at ease with L2 exclusivity. It seems to be more to do with individual preferences whereby some like their teacher to make L1/L2 connections while others do not feel this is necessary (Macaro, 2005).

Brice and Roseberry-McKibbin (2001) suggest that teachers could adopt strategies of code-switching that centre around dealing with vocabulary issues, for classroom organisation and management, for building relationships with learners, and for clarification of points of understanding.

Sert (2005) identifies teacher code-switching functions as topic switch, code-switching for affective functions, and for repetition. In code-switching for topic switch, the teacher constructs a bridge between the known (L1) and the unknown (target language content), making meaning clear. In codeswitching for affective functions, code-switching is used by the teacher to build solidarity and intimate relations with learners, thereby creating a supportive language environment in the classroom. Through repetition, code-switching is done by the teacher for clarity of meaning but Sert points out 
that this may have the unintended impact of learners losing interest in the teacher's L2 utterance, as the learners know that the teacher will repeat them in the L1, thus limiting the learners' L2 exposure.

Yataganbaba and Yildirim (2015) investigated Turkish EFL Young Language Learner teachers codeswitching from English (L1) to Turkish (L2) in their classroom interactions. The researchers established that all the teachers who participated in their study for a number of pedagogical functions such as translation, asking L1 equivalence, giving instructions, explaining, clarifying, maintaining discipline (warning and admonishing), for unofficial interactions, confirming, changing topic, assigning homework, correcting mistakes, checking homework, checking comprehension, correcting pronunciation, and signalling humorous situations. The researchers conclude that code-switching 'is not something that the teachers should avoid at all costs', but something that the teachers should not over-use (Yataganbaba and Yildirim (2015:96). The researchers, thus, call upon teachers to strike a balance between the use of the learners' L1 and the target language.

In a related study, Bozorgian and Fallahpour (2015) inquired into the amount and purpose of L1 use in EFL classrooms by teachers and learners at two English language institutes in Iran. The researchers found out that though there was a limited amount of L1 use, the teachers and learners did use codeswitching to enhance the language teaching and learning process. The researchers established that the teachers resorted to the L1 for translation (from L2 to L1), contrasting (L1 and L2) utterances, evaluation of students' contributions, giving instructions, giving the objective of an activity, eliciting student contribution, commenting, checking comprehension, for administrative issues (such as announcements), repeating students' utterances, reacting to students' answers, for their own false starts, creating humour, for incorporating words from the L1 culture into L2 speech, and for encouraging learner participation. As for the EFL learners, the two researchers unearthed that they used the L1 to ask questions, answer questions, scaffolding (helping each other in group tasks and other situations), self-correction, and for seeking clarification and elaboration. Bozorgian and Fallahpour (2015:79) concluded that though the L1 was minimally used, the language teachers and learners were not reluctant to use it, and recommend that,

L1 can be used and actually should be used as an aid by the teachers to convey meaning, manage the classroom, make a friendly environment, reduce the students' anxiety, facilitate communication, elaborate on the course objectives and clarify the ambiguous points ... The students are also allowed to use their L1 for scaffolding and peer learning, but they must not use it more frequently to overshadow their L1 exposure to L2/EFL, which makes them lazy, and interferes with their L2/EFL learning. L1 should be used in a way that students L1 is an effective tool for improving and facilitating L2/ EFL learning and teaching....

Sert (2005) observes that like their teachers, learners are not always aware of the reasons for codeswitching and its functions and outcomes. Sert goes on to explain the code-switching functions that were identified by Eldridge (1996), which are equivalence, floor holding, reiteration, and conflict control. The equivalence function is whereby the learner makes use of the L1 equivalent of a lexical item in the target language, which may be done when the learner lacks the competence for using the target language explanation for the lexical item in question. In floor holding, learners fill the stopgaps with the L1, so as to avoid gaps in communication. This may be due to lack of fluency in the target language but may result in loss of target language fluency in the long term. Reiteration is a learner code-switching function in which messages are reinforced, emphasised or clarified and may be because the learner has failed to transfer meaning exactly in the target language, or may be done to show the teacher that the learner has comprehended. Finally, code-switching for conflict control is whereby the student code-switches to avoid misunderstandings (Sert, 2005).

In his study on code-switching in ESL teaching in Jaffna, Sri Lanka, Canagarajah (1995) categorised teacher code-switching into two broad categories, which are code-switching for classroom management and code-switching for content transmission. Code-switching for classroom management includes when opening the class, negotiating directions, requesting help, managing discipline, for teacher encouragement, teacher compliments, teacher commands, teacher admonitions, mitigation, 
pleading, and for unofficial interactions. Code-switching for content transmission includes for review, explanation, negotiating culture relevance, parallel translation, and for unofficial student collaboration (Canagarajah, 1995).

Lasagabaster (2013) investigated the teachers' use of learners' L2 in Content and Language Integrated Learning (CLIL) contexts in Colombia and found out that teachers used the learners L1 to explain, clarify, save time, make comparisons between the L1 and the L2, to make students aware of the importance of their L1, to develop confidence in learners, to foster debate, to discipline learners, and to give instructions.

In a related study, Lee (2010) investigated the use of code-switching by ESL teachers in secondary schools in Malaysia, and found out that the majority of the teachers said code-switching should be used in the English classroom but it should be used to a limited to specific purposes, that is, the teachers advocated the maximisation of the target language. The teachers revealed that they saw the need for code-switching to help learners feel comfortable and confident, to allow weaker students to comprehend the text being used, and to aid learning. In addition, teachers agreed that code switching does promote bilingualism and it facilitates second language learning. Code-switching was also seen as a strategy for the teaching and learning process. On top of that, teachers believed that code switching helped students relate their first language (L1) to their second language (L2). The use of code switching in instruction helped students clear doubts and uncertainties over a subject matter (Lee, 2010).

In Japan, McMillan and Rivers (2011) investigated the attitudes of native-English teachers towards teacher and student use of students' L1 in EFL classes at a Japanese university. In the study the teachers proffered both positive and negative sentiments about teacher and student use of learners' L1. Some of the reasons that were advanced in support of teachers' use of learners' L1 include facilitation of communication between students and the teacher, for complex definitions and instructions, for building rapport with students, for creation of humour, for demonstrating an appreciation of learners linguistic and cultural identity, for aiding vocabulary learning, for translation and comparing the L1 and the L2, and for the promotion of multilingualism. However, some of the teachers also felt that teachers' avoidance of learners' L1 would result in more negotiation of meaning in the L1, would cater for students' own L2-only use preference, would discourage student L1 use, and would be in keeping with policy. Arguments that were advanced in favour of student L1 use include facilitation of successful communication with the teacher and the rest of the class, facilitation of learner-learner interaction and peer assistance, catering for students' low L2 proficiency levels, building rapport in the classroom through humour, as well as acting as a form of needs L2 needs analysis. However, some of the teachers felt that allowing student L1 use would be tantamount to justifying learner laziness or off-task behaviour. Some were also of the view that student L1 avoidance would promote thinking in English, and some felt that the L1 should be used in emergency situations only. The researchers then recommend that policy should not be stagnant but evolving:

Teachers, as reflective practitioners and professional decision-makers, should be encouraged by program managers to develop localised strategies for maximising TL comprehension and production - strategies which are supported by research in keeping with teachers' personal beliefs (McMillan and Rivers, 2011:259).

In Ghana, Yevudey (2013) explored the pedagogical functions of code-switching in Ewe (an L1) and English (an L2) lessons and found out that code-switching was used to explain questions and statements that learners did not understand, for introducing English lessons, to correct learners who had provided incorrect answers, for acknowledgment of learners and calling on them to participate, and to facilitate understanding and vocabulary acquisition through repetition of sentences by translation.

According to Clegg and Afitska (2011), though language practices such as code-switching are a controversial issue often condemned by authorities and not accepted by teachers in sub-Saharan Africa, code-switching has important pedagogical functions. These are explaining and elaborating on 
concepts, increasing participation in the classroom, establishing good relationships in the classroom, enabling the smooth running of the lesson, as well as establishing connections with the learners' local culture.

In Botswana, Chimbganda and Mokgwathi (2012) investigated the use of code-switching by teachers in secondary schools and established that while code-switching is prevalent in Biology and Home Economics, it was less prevalent in History, and minimal in English Language lessons. The researchers conclude that code-switching cannot be wished away.

In Namibia, Simasiku (2014) investigated the perceptions of Grade 10 ESL teachers about the effects of code-switching in their classrooms and found out that the majority of the teachers viewed codeswitching as having a positive effect on learner participation and acts as a scaffold to support learners who lack proficiency in the target language. The majority of the teachers also revealed that their learners showed enthusiasm and happiness when code-switching was allowed in the classroom, while one said the learners were sad and another said the learners appeared indifferent. The teachers suggested that the learners were happy and enthusiastic when code-switching was allowed because the learners were free to express themselves in their L1, were confident they would not make mistakes, and they quickly mastered what was taught. The one teacher who said the learners' appeared sad gave the reason that the learners expected the lesson to be conducted in English but were disappointed when teachers code-switched. Simasiku's study also revealed that though teachers appreciated monolingual teaching to enhance the learners' linguistic competence in English, they saw codeswitching as tool of improving their learners' comprehension in English.

Still Namibia Simasiku, Kasanda and Smit (2015) carried out a study to find out why secondary school teachers were not using code-switching in Grade 10 English medium classrooms even in the face of the learners failing to understand what the teachers were communicating. The findings were that the teachers were hostile towards the use of code-switching, citing the language policy that insists on English only, school rules that demanded English exclusivity, lack of vocabulary in the mother tongue, misconceptions about job opportunities (the belief that is the mother tongue was used in the classroom, the learners might later fail to be employed), as well as the fear that code-switching might result in the mother tongue finding its way into the learners' writing. Hence this study seeks to find out teachers' beliefs about code-switching in ESL secondary school classrooms in Zimbabwe.

In another study, Simasiku, Kasanda and Smit (2015) investigated whether code-switching enhanced learners' academic achievement in the Caprivi Education Region of Namibia at Grade 10 level of the secondary school. The study revealed that from the point of view of teachers, code-switching had the benefits of making learners understand concepts, instructions and topics, making teacher explanations easy, keeping learners actively involved in lessons and stimulating participation. However, the teachers also revealed that the majority of their learners preferred English as the medium of instruction because it is the medium through which they should learn English and is also the medium of instruction for Namibia, so that everyone can understand since the learners have different mother tongues, because English is compulsory and beneficial, and because it is school policy to use English. However, other learners preferred to use local languages for easy communication because they lacked the vocabulary of English and were incompetent in it, and because the teachers allowed the L1 to be used when learners were working in groups. The majority of the teachers also preferred their learners to use English for the following reasons: the belief that learners cannot learn English through local languages, English is the only medium of instruction or international language used world-wide which is also the official language and medium of instruction for Namibia, policy demands that English be used, for learners to practise using English and improve their communication skills, all subjects are taught in English except the local language, and that learners are tested in English.

Dube and Cleghorn (1999) found out that code-switching is common in Mathematics lessons in primary schools in Zimbabwe. They found out that code-switching is mainly done for repetition to emphasise what has been said, for affective connections (to provide a linguistic bridge between the classroom and the home culture), to give instructions, and to promote understanding of important concepts. 
In a study more closely related to the current study, Nyawaranda (2000) investigated the beliefs of two secondary school teachers on the role of Shona in English Language lessons and established that the two teachers had contrasting views. In the study, one of the teachers seems to consider herself as a good model for her second language learners and resorts to the use of English only in the English lessons, suggesting that she fears that the learners might develop negative attitudes towards English if Shona is used, and that the students might be deprived of the opportunity to practice English for examination purposes. Nyawaranda (2000:32) then observes that this teacher's 'non-use of the mother tongue in theory and practice suggests an ESL model for instruction that is influenced by a 'purist' view.' However, the other of the two teachers in Nyawaranda's study sees Shona and English as playing a complementary role in the English lessons. The teacher uses Shona to bridge the gap between the students L1 and English, to repeat for effect, to instil a sense of confidence in the learners, to explain lexical items that may be non-existent in the target language, to give contextual cues, and to accommodate learners' lack of proficiency in English, resulting in his lessons flowing more easily. Nyawaranda concludes that this teacher's use of Shona in English lessons is in contradiction with Zimbabwe's language policy on instruction, which states that all instruction from the third grade of the primary school (before the policy was amended in 2006 to make English the compulsory medium of instruction from the first year of secondary education) except in the teaching of local languages should be in English. This continued use of Shona in ESL instruction, shows the complexity of choosing what language to use in the classroom, showing that language use in the classroom cannot be effectively legislated by language policy (Nyawaranda, 2000).

\subsubsection{Negative Impact of Code-switching in the Classroom}

Despite the positive gains of L2-L1 code-switching reviewed in the above section, some arguments have been put forward against code-switching in L2 teaching and learning. According to Macaro (2005:68), 'By far the majority of bilingual teachers regard codeswitching as an unfortunate and regrettable but necessary.'

Modupeola (2013) feels that if code-switching by the teacher is used to compensate for the teacher's own deficiency in the target language, this sends the wrong message to the learners, implying that the teacher should be a good model for the 'Standard English' that the learners should emulate. Modupeola further argues that code-switching through repetition of an instruction or an idea in another language may slow down the rate of learning the target language. This view is shared by Sert (2005) who observes that over-reliance on code-switching may result in the learners listening only to the L1 repetition and ignore the L2 utterance, which will limit the learners' exposure to L2.

Cook (2002) observes that in instances where classroom members do not share the same L1, codeswitching may create problems as some learners will feel left out in the teaching and learning process. Since it is impossible for the teacher to relate to all the mother tongues of the learners in the classroom, code-switching should be avoided and the target language should be used consistently instead.

Another argument is advanced by Eldridge (1996:310), who asserts that if learner code-switching continues in the classroom, it may result in fossilisation and 'the language acquired would then become a hybrid variety, and the learners would find themselves severely linguistically deprived with target language code monolinguals (Siegel 2009:48). In addition, code-switching may be associated with the notion of negative transfer, 'the inappropriate use of the first language (L1) or dialect (D1) when speaking or writing the second language (L2) or dialect (D2)'

Furthermore, Sampson (2011) argues that if learners feel that code-switching is allowed for all communicative functions in the classroom, they may deliberately overuse the phenomenon even when they have the proper linguistic resources to express themselves in the L2.

Also, Krashen and Terrell (1983) call for L2 exclusivity in L2 learning, arguing that language learners acquire the L2 through the same natural way they learn their L1. In relation to this, Macaro (2005:65) observes that 
Code-switching by the bilingual teacher is contentious because it flies in the face of the notion of comprehensible input. If learners learn by adding to their store of knowledge, just a little bit more of the new language via inference $(i+1)$, then why should they need to know what the equivalent linguistic element is in their own language?

On the same issue of comprehensible input, 'Code-switching by the bilingual teacher is contentious because it is believed to cut down on the amount of exposure that the learner has to the L2' (Macaro, 2005:66).

Macaro (2005) also observes that code-switching becomes a contentious issue because it is associated with the grammar-translation method which now has become unfashionable. Apart from that codeswitching is also a contentious issue because some national agencies try to control what teachers do in the classroom, imposing certain methodologies despite lack of evidence in favour of their propagation. Furthermore, when used by L2 learners, code-switching is regarded by some teachers as off-task, deviant or disruptive behaviour and as evidence of not thinking as much as possible in the target language (Macaro, 2005).

In light of the arguments for and against code-switching in L2 teaching and learning, Macaro (2009:38) calls for optimal use of code-switching, whereby 'code-switching in broadly communicative classrooms can enhance second language acquisition and/or proficiency better than second language exclusivity.' Macaro (2005) also calls this a theory of optimality, that is, how and when code-switching leads to 'language learning, learning how to learn, and to the development of communication skills. Macaro also says to advocate total freedom to code-switch at will is not acceptable and rejects phrases such as 'use the L2 as much as possible' or 'judicious use of L1' for being not informative enough.

In light of the negative aspects of code-switching in L2 learning put forward above, the present study sought to inquire into the perspectives of selected learners of English on their teachers' codeswitching in the teaching and of English.

\subsection{Methodology}

The study adopted the qualitative research design that employed focus group discussions as the data gathering tool.

\subsection{Qualitative Research}

According to Matthews and Ross (2010), qualitative research seeks to find out the subjective understandings, feelings, opinions and beliefs and data are gathered in the words or expressions of the research participants themselves.

Unlike quantitative research which seeks statistical analysis, qualitative research seeks insight (Fraenkel and Wallen, 1990; Nyawaranda, 2003).

\subsection{Sample}

Two secondary schools, an urban boarding school that also enrols day learners and a rural day school, as well as the learners, were purposively sampled. This is in keeping with qualitative research, which,

usually works with purposive non-probability samples because it seeks to obtain insights into particular practices that exist within a particular location, context and time. Informants are therefore identified because they are known to enable the exploration of a particular behaviour or characteristic relevant to the research (Gray, 2014:174).

Creswell (2013) also asserts that in purposive sampling the researcher chooses individuals and sites for investigation for the reason that they can purposefully inform an understanding of the research 
problem and central phenomenon of the research. Purposive sampling is 'sampling in a deliberate way, with some purpose or focus in mind' and it may be convenient sampling, 'where advantage is taken of cases, events, situations or informants which are close at hand' (Punch, 2005:187). In the same vein, Clark (2011, p. 123) describes purposive sampling as 'a nonprobability sampling procedure that involves elements based on the researcher's judgment about which elements will facilitate his or her investigation.'

The two secondary schools for this study, School A and School B, were purposively sampled on the basis of their different locations and distinct characteristics.

School A is an urban government boarding secondary school, while School B is a rural day secondary school that is run by the Masvingo Rural District Council. I therefore felt that these distinctly different secondary schools would provide useful, insights into learners' perceptions their teachers' codeswitching in the teaching of English in secondary schools in Zimbabwe.

From these two secondary schools, two Form Three English Language (one class per school) and two Form One classes (one class per school) were purposively sampled for investigation. Form Three and Form One classes in Zimbabwe are considered non-terminal examination classes in Zimbabwe, hence I felt that the schools would give me greater access to the participants (learners of English). The classes were also sampled on the basis of their being taught by trained and experienced English Language teachers who are able to speak the learners' L1.

From the four classes, I requested the teachers of English of the four classes to purposively sample ten learners per class so that they would participate in four separate focus group discussions. The teachers purposively selected the learners using the criterion of high English proficient, moderate proficient, and low proficient learners per class.

\subsection{Data Collection Tool}

Data was gathered using focus group discussions in keeping with qualitative research. One of the advantages of focus groups is that the interviewer 'creates a supportive environment, asking focused questions to encourage discussion and the expression of differing opinions and points of view' (Marshall and Rossman, 2006:114). Furthermore, focus groups encourage communication between, as well as participation by, participants (Kitzinger, 1994). Other advantages are that they are a faster and easier way of collecting qualitative data than in-depth interviews, since a range of views can be collected in less time than it would take for individual interviews, they generate discussion that can bring to the fore a variety of issues, and may be less influenced by the interviewer than the one-to-one interview (Yates, 2004). In addition, focus groups produce data and insights that would not be accessible in the absence of the kind of interaction that obtains in groups (Morgan, 1988). In addition to this, 'group situation can also stimulate people in making explicit their views, perceptions, motives and reasons', and focus groups 'are inexpensive, data-rich, flexible, stimulating, recall-aiding, cumulative and elaborative' (Punch, 2005:171). Focus groups also offer opportunities for clarifications of responses, for probing and for observation of non-verbal responses (Stewart et al, 2007). They also 'allow for the synergistic building up of data as respondents add to the views expressed by others' (Gray, 2014:469). Other advantages of focus group discussions given by Cohen, Manion and Morrison (2011) are generating data quickly and at low cost, gathering data on attitudes, values and opinions, empowering participants to speak out and in their own words, and encouraging groups, rather than individuals, to express their thoughts, and providing a greater coverage of issues than would be the case in a survey.

This inquiry carried out focus group discussions with four groups of ten ESL learners each group. Each focus group discussion session lasted about one hour. The discussion sessions were audio-taped and later transcribed for analysis. The discussions focused on the learners' perceptions on codeswitching by the teachers of English. 


\subsection{Results}

In the focus group discussions with learners from the two schools, all the learners confirmed that their teachers sometimes code-switched to explain some difficult words, when, when cracking jokes, when students are misbehaving, and generally "when students don't understand", "for explaining some concepts", "giving instructions", "for explaining some statements", and "when cracking jokes", "when there is need to use Shona, like when we we don't understand what she is saying in English so she can use Shona", "when there is a story which has an aspect of our daily lives, ... which we don't know, so she tries to put it in Shona."

The learners expressed mixed reactions to the teacher's code-switching. Some said they saw it as good for the teacher to code-switch during English Lessons and the major reasons given were that it breaks monotony, makes jokes more interesting, and it makes learners understand better. Those were against code-switching by their teacher argued that the teacher might pass on the habit to learners, that it affects their English yet the exam will be in English only, and that since they are English lessons they must be taught in English only. Below are their responses:

"I feel that the teacher should code-switch because English is our second language and Shona is our mother language. It makes the lesson more interesting, rather than speaking English throughout the whole lesson, it will become monotonous. Also, some jokes are interesting when they are said in Shona, they may not make sense when they are spoken in English."

"When the teacher uses Shona I find the lesson will be enjoyable."

"When the teacher code-switches we as students understand his explanations better."

"Shona should be separated from English. This is to encourage pupils to get used to English for use in the exams. Also, my mother language is Ndebele so it's difficult for me to understand the teacher when he uses Shona during the English lesson."

"I like it when the teacher uses Shona because it helps some of the kids who do not easily get a point in English but better understand it when it is explained in their mother tongue."

"It's good when the teacher switches to my home language for my better understanding for example to explain the word 'rude' in register."

"It is good when the teacher explains a point in detail so that everyone could understand."

"The teacher should not use Shona because it affects our English. Exams are written in English so if the teacher uses Shona this will affect us when writing our exams. Also, it will make us develop a bad habit of using Shona all the time."

"The teacher should use English only. Since it is an English lesson it needs to be taught in English."

"It's good only when cracking jokes but for explaining words English should be used."

"It's good for the teacher to use Shona to express herself clearly to students who do not understand."

"It's ok for the teacher to use Shona during English lessons because some complex words cannot be easily understood if explained in English."

"The teacher should continue to use Shona words because we sometimes come across confusing words which will be better understood in Shona."

"The teacher should use Shona but not all the time. It helps pupils to understand better."

"I like it when the teacher uses Shona since it makes everything clear and sensible to everyone." 
"The teacher should speak in Shona but on rare cases, only when the class failed to understand the teacher's explanations."

"It's not good for the teacher to speak Shona during English lessons because he should lead by example. We should learn English from him."

"I don't like it because if he switches to Shona we will also use Shona but he is the one who should lead us by example, so if he leads us on wrong path we will also go wrong."

"It's good because we will understand better."

“On the other hand it's good because some people don't understand English, especially mu colleagues and it will help part of the class ... it doesn't also help because some people let's take for example someone comes from Europe, he or she doesn't know Shona so for you to speak to him in English, eh we have to learn to speak English other (rather) than Shona during English lessons."

"It's good for the teacher to use Shona because the teacher will be trying to make you understand. After explaining in Shona and the teacher asks if we ... understand, there will be an overwhelming response."

"The teacher must use Shona but not often for understanding of instructions."

"The teacher should use Shona when necessary for example (for) instructions and jokes."

"If the teacher uses Shona it's a disadvantage to those (learners) who don't understand Shona."

"The teacher should not use Shona but students should because teacher is an English teacher who passed so she must use English."

"I don't blame the teacher for speaking in Shona because Shona can just pop out of your mouth."

"The teacher should switch to Shona so that what he is saying will be clear to those who do not understand (English)."

"It is good for the teacher to use Shona a little for better understanding. There are some slow learners who cannot get what what the teacher will be saying so Shona must be used to explain hard concepts."

"The use of Shona by the teacher makes us understand some concepts which might be strange to us."

"When my teacher uses Shona during English lessons this makes me to understand better."

"It's good for the teacher to use both English and Shona because if she uses English only this will make difficult for us to understand since most of the time we speak Shona."

"She should use Shona words so that the students might not feel neglected because children who can't understand English will not be able to participate. They will feel that they are the worst students in the class."

"It's better for the teacher to speak Shona to shed light on the students so they can later speak English fluently."

"The teacher should use Shona because if she speaks English only my colleagues - some of them might be in topsy-turvy situation if the teacher doesn't speak in Shona."

"If the teacher uses Shona during English lessons this will negatively affect the students' grasp of English."

"I don't see any benefit for us when the teacher uses Shona." 
"The teacher should use English only because pupils should be able to speak and understand English by learning from the teacher."

\subsection{Discussion}

The overall picture that emerged from both Schools A and School B is that all the four teachers taught the learners who participated in the study code-switched into the majority of the learners' L1 (Shona).

The learners, revealed that their teachers 'sometimes' code-switched mainly to explain difficult words, concepts and statements, when cracking jokes, when students 'don't understand', when giving instructions, and when students are misbehaving.

Some of the teacher code-switching situations that emerged in this study seem to fit into Ferguson's (2003) categorisation of code-switching for the curriculum (for example explanation, clarification, exemplification, emphasising, checking understanding) - all these to enhance understanding - codeswitching for management of classroom discourse (for example when students misbehave), for interpersonal relations (for example joking).

Similarly, the teacher code-switching situations that emerged in this study also seem to be closely related to Brice and Roseberry-McKibbin's (2001) suggestion that teachers could adopt strategies of code-switching that centre around vocabulary issues (such as defining and explaining as unearthed in this study), classroom organisation and management (such as giving instructions and reprimanding), for building relationships with the learners (such as joking), and for clarification of points.

Some of Baker's (2006) teacher code-switching categories, that is, emphasising, substituting words (defining using the L1 equivalence of a word), clarifying, as well as creating humour.

The L2 teachers' code-switching situations that came out in this study also roughly correspond with the teacher code-switching functions that were identified by Al-Nofaie (2010), which are eliciting language, checking comprehension, giving instructions, checking for sense, and facilitating teacherstudent relationships.

What emerged in this study regarding code-switching by teachers of English also seem to confirm what emerged in Yevudey's (2013) study, in which the researcher established that teachers in ESL classes in Ghana code-switched for explanations, acknowledgements, calling on learners to participate, as well as repeating sentences (for emphasis) in the learners' L1, so as to enhance the learners' understanding.

Some of the teacher code-switching situations that were identified in this study were also observed by Yataganbaba and Yildirim (2015) in their study of Turkish EFL Young Language Learner teachers' code-switching. The teacher code-switching functions that they identified that correspond with those that I identified in the current study on two secondary schools in Zimbabwe include translation (from L2 to L1), giving instructions, explaining, clarifying, checking comprehension, and signalling humorous situations (joking).

In the same vein, Bozorgian and Fallahpour (2015) investigated the amount and purpose of L1 use in EFL classrooms by teachers and learners and some of the teacher code-switching functions that came out of their study that are more or less similar to those that came out of my current inquiry include translation, giving instructions, contributions, repeating students' utterances (emphasising), as well as creating humour (joking).

From the focus group discussions that I held with the learners of English at the two secondary schools, a common theme that emerged from the majority of the learners is that code-switching by teachers of ESL is good as it makes the learners understand what is being taught.

The issue of teacher code-switching to make learners understanding or comprehend what is being taught also seems to be common among the teacher code-switching functions suggested or suggested 
by many scholars and authors. These include dealing with vocabulary issues, clarification of points of understanding (Brice and Roseberry-McKibbin, 2001), repetition for clarity of meaning (Sert, 2005), code-switching for curriculum (Ferguson, 2003), to lower language barriers between speakers (teachers) and audience (learners), code-switching to emphasise a point (for clarity), to express a concept that has no equivalent in the culture of the other language, to clarify a point (Baker, 2006), and teacher code-switching for explaining and elaborating concepts (Clegg and Afitska, 2011). Hallbach (2012:33) also seems to allude to the importance teacher code-switching to aid learner understanding by observing that the learning of new and complex material requires the L1 medium because

As students move up into higher grades, and the contents that have to be taught become increasingly more complex, teachers find it more difficult to deal with the challenge ... the combination of new concepts to be learnt with a foreign medium to do so. Not knowing how to face this challenge, many teachers finally resort to students L1 for these more complex explanations.

Most studies that have been carried out on L2 teacher code-switching also seem to have unearthed learner understanding as a common teacher code-switching function. Examples are translation, asking L1 equivalence, explaining, clarifying, checking comprehension (Yataganbaba and Yildirim, 2015), translation, contrasting (L1 and L2) utterances, repeating students utterances (for emphasis and clarity) (Bozorgian and Fallahpour, 2015), teacher code-switching to convey and check comprehension of grammar and meanings (Choong, 2006), teacher code-switching for content transmission (explanation and parallel translation) (Canagarajah, 1995), teacher code-switching as a compensatory strategy to cater for low L2 proficiency among learners (Makulloluwa, 2013). Further examples that reflect code-switching to make learners comprehend include teacher code-switching to explain, clarify, make comparisons between the L1 and the L2 (Lasagabaster, 2013), teacher codeswitching for complex definitions and instructions, for aiding vocabulary learning, for translation, for comparing the L1 and the L2 (McMillan and Rivers, 2011), teacher code-switching to explain questions and statements, to facilitate understanding and vocabulary acquisition through repetition of statements by translation (Yevudey, 2013), and teacher code-switching to repeat for effect, to explain lexical items, to give contextual cues and to accommodate learners' lack of proficiency in English (Nyawaranda, 2000).

Also on the need for teachers to use code-switching for learners understanding as revealed by the learners in the current study, Macaro (2005) observes that some (slow) learners get frustrated when they cannot understand the teacher's L2 input and the learners, therefore, are comfortable with the teacher's code-switching so as to understand words and phrases. Macaro (2005:70) also alludes to the fact that even fast learners may also have a positive attitude to teacher code-switching since 'There is no evidence pointing in the direction of higher achieving learners (or fast learners) feeling more at ease with L2 exclusivity.'

In the current study the learners' positive perception of their teachers' code-switching seems to confirm Atkinson's (cited in Nyawaranda, 2000) argument that a teacher who ignores the students' L1 in the classroom is most likely to teach with less than maximum efficiency. In agreement is Macaro (2000) who argues that code-switching has no negative impact on the quantity of learners' L2 production but may actually increase and improve it if expertly done. Also, L2 teachers who do not code-switch deny their learners translation as an important learning task, pre-learning activities which trigger appropriate combinations of listening strategies, as well as certain classroom activities that are useful (Macaro, 2005).

The other reasons that were given by the learners for their favourable perception on their teachers' code-switching in the current study were that it breaks monotony and makes jokes interesting, accommodates all students, and that teacher code-switching can occur spontaneously so the teacher should not be blamed for it. 
The teacher code-switching function of joking that was advocated by some of the learners in my current study seems to be common among code-switching functions that have been proposed or identified by many scholars and researchers, for instance, teacher code-switching for building relations with learners (Brice and Roseberry-McKibbin (2001), teacher code-switching for affective functions (building solidarity and intimate relations with learners, thereby creating a supportive language environment in the classroom) (Sert, 2005), teacher code-switching to make a friendly environment and reduce students' anxiety (Bozorgian and Fallahpour (2015), teacher code-switching to create an effective classroom environment (Makulloluwa, 2013), teacher code-switching for building rapport with students and for creation of humour (McMillan and Rivers, 2011), teacher codeswitching for establishing good relationships in the classroom (Clegg and Afitska, 2011), teacher code-switching for facilitating teacher-student relationships (Al-Nofaie, 2010), and code-switching for interpersonal relations (Ferguson, 2003).

It also came out from the learners that teacher code-switching is good because it accommodates all learners in the learning process (assuming the learners share the same L1). This is supported by Alenezi (2010) who observes that the teacher's code-switching can build learners' confidence and invite participation. This also confirms Simasiku's (2014), which established that secondary school ESL teachers in Namibia believed that their code-switching had a positive effect on learner participation and made the learners enthusiastic and happy. In a related study, Simasiku, Kasanda and Smit (2015) found out that ESL secondary school teachers in the Caprivi Education Region of Namibia revealed that code-switching had the effect of keeping learners actively involved in the lessons and it stimulated learner participation.

It also emerged from this study that the some of the learners of English were tolerant of their teachers code-switching because code-switching can occur spontaneously. This is confirmed by Ferguson, cited in Baker (2006:295), who states that teacher code-switching,

Seems to arise naturally, perhaps inevitably, as a pragmatic response to the difficulties of teaching content in a language medium over which pupils have no control ... much switching takes place below the level of consciousness. Teachers are often simply not aware of when they switch languages, or indeed if they switch at all.

Sert (2005) also observes that the use of code-switching by teachers is not always done consciously.

The fact that the majority of the learners in my study viewed their teachers' code-switching in a positive light would suggest that the learners preferred that the teachers used bilingual approaches and methods of L2 teaching.

However, some of the learners of English - though they were in the minority - revealed an unfavourable perception of their teachers' code-switching in the focus group discussions that I held with them. Some of the reasons that came from the learners for being against their teacher's codeswitching were that the teacher might pass on the habit of code-switching to the learners, that codeswitching by the teacher (negatively) affects their English yet the examination will be written in English only, that English should be taught in English only, that the teacher should lead by example (through using English only) and desist from following the 'wrong path' (code-switching), that the teacher's code-switching was not good because it disadvantaged those whose L1 was not Shona, and that the teachers' code-switching negatively affected their (learners') grasp of English.

The learners' view that the teachers' code-switching would have a negative effect on their learning of English seems to be confirmed by Modupeola (2013) who says teacher code-switching by repetition may slow down the rate of target language learning. In the same vein, Sert (2005) asserts that overreliance on code-switching by L 2 teachers may limit learners' exposure to the target language.

That some of the learners were against the teachers' code-switching because they wanted their teachers of English to lead by example or to act as models from whom they should learn English appears to confirm one of the findings of Nyawaranda's (2000) study, in which one of the teachers 
who participated in the study desisted from the learners' L1 (Shona) when teaching English, seemingly because she considered herself as a good model for her learners of English, suggesting that she feared that the learners might develop a negative attitude towards English if Shona was used, and that the students might be deprived of the opportunity to practice English for examination purposes. The issue of English examinations which are written in English only in Zimbabwe also came out as one of the reasons why some of the learners in the current study had a negative perception of the teacher's code-switching.

Another reason that was given for some of the learners' negative perception on teacher's codeswitching was the fear that the teacher might pass on the habit to learners. This is confirmed by Sampson (2011) who argues that if learners feel that code-switching is allowed for all functions in the classroom, they may over-use code-switching even when they have the proper linguistic resources to express themselves in the target language.

Apart from the above reason, it was also pointed out that the teachers' code-switching tended to disadvantage those learners whose L1 was not Shona. This observation is also shared by Cook (2002) who explains that in instances where classroom members do not share the mother tongue, codeswitching make some learners feel left out of the learning process since the teacher cannot speak the first languages of all the learners in the classroom.

In a study related to the current study, Simasiku (2014) established that some ESL teachers in secondary schools in Namibia felt that their students were sad when their teachers code-switched, because the learners expected the lessons to be conducted in English but were disappointed when code-switching was used. In another study, Simasiku, Kasanda and Smit (2015) found out that the majority of ESL secondary school learners in the Caprivi Education Region of Namibia preferred that their teachers to use English only because they believed English is the medium through which they should learn English and is also the medium of instruction. Another reason was that the teacher should use English only so that everyone can understand since the learners had different mother tongues, and because English is compulsory and perceived to be beneficial, and also because it is school policy to use English only. This points to the high status that is accorded to English in Namibia. The same situation also obtains in Zimbabwe so this could also explain why some learners in the current study preferred that the teachers use English only. The high status that is given to English in Zimbabwe, according to Chiwome (1996), dates back to the colonial era when viewed as the gateway to success, the language without which the Cambridge School Certificate would not be valid.

Even after Zimbabwe gained her political independence from Britain in 1980, English continued to enjoy its high status across many facets of life as articulated by Nyawaranda (1998:48) thus:

English is a very important subject on the school curriculum. Because of its high status as an official language, because of its perceived international status, and because it is a compulsory subject at ' $\mathrm{O}$ ' Level, English receives a disproportionate amount of attention in the secondary school curriculum; in fact, it takes the lion's share of the time allocated to subjects on the school's time table. Even outside the school life, English is still highly regarded in the wider community.

In the current study, the learners who were of the view that English should be taught in English only seemed to be advocating that their teachers of English use the monolingual approach to L2 teaching which argues for an English-only paradigm, as it views the L1 as interfering with L2 acquisition. These learners who were against code-switching by their teachers, thus, appeared to prefer to be taught English through approaches and methods such as the Natural Approach and the Direct Method.

\subsection{Conclusion and Recommendations}

What also emerged from the study is that the ESL learners was that the learners agreed that their teachers sometimes code-switched. Also, the learners had a largely positive perception of their teachers' code-switching as a tool that facilitates understanding and this useful function is alluded to 
by Brice and Roseberry-McKibbin (2001), Ferguson (2003), Sert (2005), Baker (2006), Clegg and Afitska (2011), and Moduopela (2013).

On the other hand, some of the learners, though being a minority, expressed an unfavourable perception of their teachers' code-switching and this is supported by scholars such as Sert (2005), Sampson (2011), Moduopela (2013), and Simasiku (2014).

From the results of the study, it can, thus, be concluded that code-switching by ESL teachers and learners is very much alive in secondary schools in Zimbabwe and both the teachers and learners find it to be a useful L2 teaching and learning tool, although they are also aware of the possible negative impact of the phenomenon in the L2 classroom. It can also be concluded that teachers are aware of the relationship between code-switching and New Englishes, and that these New Englishes are a legitimate varieties that may be taught in schools, although the 'standard' variety is still the dominant variety that is enjoying a higher status, and therefore some teachers would prefer that the variety should continue being taught.

In light of the findings of the study and the conclusions reached in the preceding section, therefore, I make the recommendations to language policy planners, the Ministry of Primary and Secondary Education, ESL teachers, as well as to the national examination board. A recommendation is also made for further research.

To language policy planners in Zimbabwe and other 'Outer Circle' countries, I recommend that the English-only policy in secondary education be revised, as code-switching evidently plays an important pedagogic function in the teaching of ESL. This is supported by Nyawaranda (2000), who posits that the continued use of Shona in ESL instruction shows the complexity of choosing what language to use in the classroom. Hence language use in the classroom cannot be effectively legislated by language policy.

There could also be need for a paradigm shift on the part of language policy planners in Outer Circle countries such as Zimbabwe from the current exo-normative model to the endo-normative or nativised model which would be advantageous not only to teachers by legitimising the teachers' own model thereby boosting the ESL teachers' self-confidence and self-esteem (Kirkpatrick, 2007) but also the learners who may easily identify with this model and thus find it easier to master.

To the Ministry of Primary and Secondary Education, I recommend that workshops be convened for ESL teachers so that the teachers are sensitised not only to the important role that code-switching may play in ESL teaching and learning, but also to how best this teaching and learning tool may be contextually employed without compromising the learners' mastery of the target language.

To ESL teachers, I recommend that they desist from being servants of either monolingual or bilingual teaching approaches and methods of L2 teaching but to be guided by Kumaravadivelu's (2006) Postmethod pedagogy in which the teacher's decision to code-switch or not, when to code-switch and how frequently to code-switch may be premised on principles of particularity (sensitivity to context), practicality (teacher-generated theory of practice), and possibility (a critical reflection of prevailing social and historical conditions). In short, Kumaravadivelu argues for what works in the classroom and I am inclined to agree with him. In support of this is Larsen-Freeman (2000) who rejects absolutism or the belief that a single specific method can be the best, and advocates relativism or pluralism. The author avers that 'rather than adopting or rejecting methods in their entirety as being suitable for a particular context, different methods or parts of methods, should be practised in the same teaching context' (Larsen-Freeman, 2000:1820).

In the same vein, it would be prudent for ESL teachers to decide whether or not to code-switch, when and how frequently by taking into cognisance what Prabhu (1990) calls a sense of plausibility, that is, a sense of the teacher's subjective understanding or personal conceptualisation of teaching carried out in the classroom and its envisaged effect, a kind of pedagogical intuition that emanates from a teacher's experience as a learner, teacher exposure to teaching methods, what the teacher knows or 
thinks about other teachers' actions or opinions, and the teacher's experience as a parent or caretaker. In support, Tribble (1997) calls for teacher independence, avoidance of fixed ideas, and promotion of fashionable formulas, exploration of principles and experimenting with teaching techniques in the classroom (of which code-switching may be one such technique).

To examination boards for countries in 'Outer Circle' countries such as the Zimbabwe School Examinations Council, I recommend, without advocating for acceptance or condoning of errors, that the examination boards be sensitive to aspects of local English varieties rather than prescribe exonormative or native speaker models which both the ESL teachers and learners would find difficult or impossible to achieve. It is my submission that the goal of L2 instruction should be communicative competence and this is supported by Brown (1987), Richards and Rodgers (2007), Hoff (2013), and Ohmaye (2013), not necessarily native speaker proficiency.

Finally, although this study has apparently gained useful insights into the use of code-switching in ESL teaching and learning in secondary schools in Zimbabwe thereby contributing to the body of knowledge on L2 pedagogy, there might be need for further research into what is obtaining at other secondary school types such as mission boarding schools and private schools.

\section{References}

Alenezi, A.A. (2010). 'Students' language attitudes towards using code-switching as a medium of instruction in the College of Health Sciences: An exploratory study.' ARECLS, 7, 1-22.

Al-Nofaie, H. (2010). 'The attitudes of teachers and students towards using Arabic in an EFL classroom in Saudi public schools: A case study.' Novistas ROYAL, 4(1), pp. 64-95.

Baker, C. (2006). Foundations of bilingual education and bilingualism. Clevedon: Multilingual Matters.

Bozorgian, H. \& Fallahpour, S. (2015). 'Teachers' and students' amount and purpose of L1 use: English as a foreign language (EFL) classrooms in Iran.' Iranian Journal of Language Teaching Research, 3(2), pp. 67-81.

Brice, A. \& Roseberry-McKibbin, C. (2008). 'Choice of languages in instruction.' Teaching Exceptional Children, 33(4), pp. 10-16.

Brown, H.D. (1987). Principles of language learning and teaching. Harlow: Pearson ESL.

Brown, H.D. (2000). Principles of language learning and teaching. Harlow: Pearson ESL.

Canagarajah, A.S. (1995). 'Functions of code-switching in the ESL classrooms: Socialising bilingualism in Jaffna.' Journal of Multilingual \& Multicultural Development, 16(3), pp. 173-195.

Chimbganda, A.B. \& Mokgwathi, T. (2012). 'Code-switching in Botswana's ESL classrooms: A paradox of linguistic policy in education.' International Journal of English Linguistics, 2(2), pp. 2132 .

Chimhundu, H. (1997). Intergovernmental conference on language policies in Africa. Final Report. Harare: UNESCO.

Chiwome, E.M. (1996). A social history of the Shona novel. Eiffel Flats: Juta.

Choong, K.P. (2006). Teachers' College, Columbia University Working Papers. TESOL and Applied Linguistics 6(1) pp. 1-3.

Clark, A. (2011). An invitation to social research: How it's done. Belmont: Wadsworth Cengage Learning. 
Clegg, J. \& Afitska, O. (2011). 'Teaching and learning in two languages in African classrooms.' Comparative Education, 47(1), pp. 61-77.

Cohen, L., Manion, L. \& Morrison, K. (2011). Research methods in education. London \& New York: Routledge.

Constitution of Zimbabwe Amendment (No. 20) (2013). Harare: Government Printers.

Cook, V. (2001). 'Using the first language in the classroom.' Canadian Modern Language Review, 57, pp. 402-427.

Cook, V. (2002). Portraits of the L2 user. Clevedon: Multilingual Matters.

Cook, V. (2008). Second language learning and language teaching. London: Hodder and Stoughton.

Cook, V. (2012). 'Multi-competence.' Available at: homepage.ntlworld.com/Vivian.c/Writings/Papers/MCentry.htm

Corder, S.P. (1992). A role for the mother tongue. In S. Gass and L. Selinker (eds.) Language transfer in language learning. Amsterdam: John Benjamin Publishing.

Creswell, J.W. (2009). Research design: qualitative, quantitative, and mixed method approaches. Thousand Oaks: Sage.

Crystal, D. (2003). English as a global language. Cambridge: Cambridge University Press.

Deller, S. \& Rinvolucri, M. (2002). Using the mother tongue. London: Delta Publishing.

Dube, R. and Cleghorn, A. (1999). 'Codeswitching in Mathematics lessons in Zimbabwe.' Zimbabwe Journal of Educational Research, 2 (1), pp. 1-11.

El-dali, H.M. (2012). 'L1 and second language learning: A non-stop debate.' International Journal of Academic Research in Progressive Education and Development, 1(2), pp. 8-32.

Eldridge, J. (1996). 'Code-switching in a Turkish secondary school.' English Language Teaching Journal, 50(4), pp. 303-311.

Ferguson, G. (2003). 'Classroom code-switching in post-colonial contexts: Functions, attitudes and policies.' AILA Review, 16, pp. 38-51.

Fraenkel, J.R. \& Wallen, N.E.(1980). How to design and evaluate research in education. New York: McGraw-Hill.

Fromkin, V. \& Rodman, R. (1998). An introduction to language. Fort Worth: Hacourt Brace College Publishers.

Gebhard, J.G. \& Oprandy, R. (1999). Language teaching awareness: A guide to exploring beliefs and practices. Cambridge: Cambridge University Press.

Gray, D.E. (2014). Doing research in the real world. Los Angeles: Sage.

Hachipola, S.J. (2012). A survey of the minority languages in Zimbabwe. Harare: University of Zimbabwe Publications.

Harbord, J. (1992). 'The use of mother tongue in the classroom.' ELT J ournal, 46(4), pp. 350-355.

Hoff, M.S.T. (2013). L1 use in EFL instruction. Masters Thesis. Oslo: University of Oslo. 
Kadenge, M. \& Mabugu, P. (2009). 'The phonological characteristics of Shona loanwords from English.' NAWA Journal of Language and Communication, 3 (1), pp. 101-116.

Kafes, H. (2011). 'A neglected resource or an overvalued illusion: L1 use in the foreign language classroom.' International Journal on New Trends in Education and Their Implications, 2(2), pp. 128140.

Kirkpatrick, A. (2007). World Englishes: Implications for international communication and English Language teaching. Cambridge: Cambridge University Press.

Kitzinger, J. (1994). 'The methodology of focus groups: The importance of interaction between research participants.' Sociology of Health and Illness, 16(1), pp. 103-121.

Krashen, S.D. \& Terrell, T.D. (1983). The Natural Approach: Language acquisition in the classroom. Hayward: The Alemany Press.

Kumaravadivelu, B. (2003). Beyond methods: microstrategies for language teaching. New Haven: Yale University.

Kumaravadivelu, B. (2006). Understanding language teaching: From method to postmethod. Mahwah: Laurence Erlbaum Associates.

Larsen-Freeman, D. (2000). Techniques and principles in language teaching. Oxford: Oxford University Press.

Lasagabaster, D. (2013). 'The use of the L1 in CLIL classes: The teacher's perspective.' Latin American Journal of Content and Language Integrated Learning, 6(2), pp.1-21.

Lee, H.L.J. (2010). 'Code switching in the teaching of English as a second language to secondary school students.' Malaysian Journal of ELT Research, 6, pp. 1-45. Available at: www.mwlta.org.my

Mabugu, P. (2009). African Englishes: The indigenisation of English vowels by Zimbabwean Shona speakers. The Journal of Pan African Studies, 3(1), pp. 156-173.

Macaro, E. (2005). Code-switching in the L2 classroom: A communication and learning strategy. In E. Llurda (ed.) Non-native language teachers: Perceptions, challenges and contributions to the profession. New York: Springer, pp. 63-84.

Macaro, E. (2009). Teacher use of code-switching in the second language classroom. In M. Turnbull and J. Dailey-O'cain (eds.) First language use in second and foreign language learning. Clevedon: Multilingual Matters.

Macaro, E. (2014). Overview: where should we be going with classroom code-switching research? In R. Barnard \& J. McLellan (eds.) Code-switching in English-medium classes. Bristol: Multilingual Matters, pp. 10-23.

Makulloluwa, E. (2013). Code-switching by teachers in the second language classroom.' International Journal of Arts and Sciences, 6(3), pp. 581-598.

Malmkjaer, K. (1991). The linguistics encyclopaedia. London: Routledge.

Marshall, C. \& Rossman, G.B. (2006). Designing qualitative research. Thousand Oaks: Sage Publications.

Matthews, B. \& Ross, L. (2010). Research methods. New York: Pearson Longman.

Mavhunga, E.J. (2006). 'Africanising the school curriculum: A case for Zimbabwe'' Zimbabwe Journal of Educational Research, 18 (3), pp. 440-456. 
McMillan, B.A. \& Rivers, D.J. (2011). 'The practice of policy: Teacher attitudes towards "Englishonly".' System, 39, pp. 251-263.

Miles, R. (2004). 'Evaluating the use of L1 in the English Language classroom.' School of Humanities, Centre for English Language Studies, Department of English, University of Birmingham.

Moduopela, O.R. (2013). 'Code-switching as a teaching strategy: Implications for English Language teaching and learning in a multilingual society.' IOSR Journal of Humanities and Social Sciences, 14(2), pp. 92-94.

Morgan, D.L. (1988). Focus groups as qualitative research. Newbury Park: Sage.

Myers, M.J. (2008). 'Code-switching in content learning.' Realising Content and Language Learning in Higher Education, pp. 43-48.

Nguyen, M.H. (2010). 'Encouraging reluctant ESL/EFL learners to speak in the classroom.' The Internet TESL Journal, XVI(3). Available at: http:iteslj.org/Techniques/NguyenReluctantSpeakers.html

Nunan, D. \& Carter, R. (2001). The Cambridge guide to teaching English to speakers of other languages. Cambridge: Cambridge University Press.

Nyawaranda, V. (2000). 'The use of mother tongue (Shona, L1) in second language (English, L2) instruction and learning in Zimbabwe: A case of common underlying hypothesis.' Zimbabwe Journal of Educational Research, 12 (1).

Nyawaranda, V. (2003). 'Doing qualitative research.' Zimbabwe Bulletin of Teacher Education, 12 (1), pp. 1-3.

Nziramasanga, C. (1999). Report of the Presidential Commission of Inquiry into Education and Training. Harare: Government of Zimbabwe.

Ohmaye, E. (2013). Simulation-based language learning: An architecture and multi-media learning tool. In R.C. Schank (Ed.) Inside multi-media case-based instruction. Mahwah: Lawrence Erlbaum Associates, pp. 1-101.

Peresuh, M. \& Masuku, J. (2002). 'The role of the bilingual in the bilingual-bicultural education in Zimbabwe.' Zambezia, XXIX (1), pp. 27-37.

Prabhu, N.S. (1990). 'There is no best methodology - why?' TESOL Quarterly, 24(2). Available at: eric.ed.gov/?id=EJ416668

Punch, K.F. (2005). Introduction to social research. Los Angeles: Sage.

Richards, J.C. \& Rodgers, T. (2007). Approaches and methods in language teaching. Cambridge: Cambridge University Press.

Sampson, A. (2011). 'Learner code-switching versus English only.' ELT Journal, 66(3). Available at: elt.oxfordjournals.org/.../11.../elt.ccr067

Sert, O. (2005). 'The functions of code-switching in ELT classrooms.' The Internet TESL Journal, IX(8). Available at: http://iteslj.org/Articles/Sert-CodeSwitching.html

Sharma, K. (2006). 'Mother tongue use in English classroom.' Journal of NELTA, 11(1-2), pp. 80-87.

Siegel, J. (2009). Keeping creoles and dialects out of the classroom: Is it justified? In S.J. Nero (ed.) Dialects, Englishes, creoles and education. ESL and applied linguistics series, New York: Routledge, Francis Taylor Group, pp. 39-70. 
Simasiku, L. (2014). The perceptions of Grade 10 English Second Language teachers about the effects of code switching in their classrooms in the Caprivi Education Region. $\mathrm{PhD}$ Thesis. Windhoek: UNAM.

Simasiku, L., Kasanda, C. \& Smit, T. (2015). 'Barriers to code switching in English second language medium classrooms.' International Journal of English Literature and Culture, 8(2), pp. 7-13.

Simasiku, L., Kasanda, C. \& Smit, T. (2015). 'Can code switching enhance learners' academic achievement?’ English Language Teaching, 8(2), pp. 70-77.

Simensen, A.M. (2007). Teaching a foreign language: Principles and procedures. Bergen: Fagbokforlaget.

Simon, D.L. (2001). Towards a new understanding of code-switching in the foreign language classroom. In R. Jacobson (ed.) Code-switching worldwide II. Berlin: Mouton de Gruyter, pp. 311342 .

Stewart, D.W., Shamdasani, P.N. \& Rook, D.W. (2007). Focus groups: theory and practice. Thousand Oaks: Sage.

Storch, N. \& Wigglesworth, G. (2003). 'Is there a role for the use of the L1 in an L2 setting?' TESOL Quarterly, 37(4), pp. 760-770.

Tomilnson, B. (2005). English as a Foreign Language: Matching procedures to the context of learning. In E. Hinkel (ed.) Handbook of research in second language teaching and learning. Mahwah: Laurance Erlbaum.

Tribble, C. (1997). Writing: Language teaching: A scheme for teachers. Oxford: Oxford University Press.

Yataganbaba, E. \& Yildirim, R. (2015). 'EFL teachers' code-switching in Turkish secondary EFL language learner classrooms.' International Journal of Linguistics, 7(1), pp. 82-101.

Yates, S.J. (2004). Doing social science research. London: Sage Publications.

Yevudey, E. (2013). 'The pedagogical relevance of code-switching in the classroom: Insights from Ewe-English code-switching in Ghana.' Ghana Journal of Linguistics, 2(2), pp.1-22. 